\title{
Intracellular Trafficking of Cationic Carbon Dots in Cancer Cell Lines MCF-7 and HeLa-Time Lapse Microscopy, Concentration-Dependent Uptake, Viability, DNA Damage, and Cell Cycle Profile
}

\author{
Markéta Havrdová ${ }^{1, *}$, Iztok Urbančič ${ }^{2} \mathbb{D}$, Kateřina Bartoň Tománková ${ }^{3} \mathbb{D}$, Lukáš Malina ${ }^{3}$, Kateřina Poláková ${ }^{1} \mathbb{D}$, \\ Janez Štrancar ${ }^{2}$ and Athanasios B. Bourlinos 4
}

check for

updates

Citation: Havrdová, M.; Urbančič, I.; Tománková, K.B.; Malina, L.; Poláková, K.; Štrancar, J.; Bourlinos, A.B. Intracellular Trafficking of Cationic Carbon Dots in Cancer Cell Lines MCF-7 and HeLa-

Time Lapse Microscopy,

Concentration-Dependent Uptake, Viability, DNA Damage, and Cell

Cycle Profile. Int. J. Mol. Sci. 2022, 23, 1077. https://doi.org/10.3390/ ijms23031077

Academic Editors:

Antonino Mazzaglia and

Massimiliano Magro

Received: 6 December 2021

Accepted: 14 January 2022

Published: 19 January 2022

Publisher's Note: MDPI stays neutral with regard to jurisdictional claims in published maps and institutional affiliations.

Copyright: (C) 2022 by the authors. Licensee MDPI, Basel, Switzerland. This article is an open access article distributed under the terms and conditions of the Creative Commons Attribution (CC BY) license (https:// creativecommons.org/licenses/by/ $4.0 /)$.
1 Regional Centre of Advanced Technologies and Materials, Czech Advanced Technology and Research Institute (CATRIN), Palacký University Olomouc, Křižkovského 511/8, 77900 Olomouc, Czech Republic; katerina.polakova@upol.cz

2 Laboratory of Biophysics, Condensed Matter Physics Department, Jožef Stefan Institute, Jamova Cesta 39, 1000 Ljubljana, Slovenia; iztok.urbancic@ijs.si (I.U.); janez.strancar@ijs.si (J.Š.)

3 Department of Medical Biophysics, Faculty of Medicine and Dentistry, Institute of Translational Medicine, Palacký University in Olomouc, Hněvotínská 3, 77515 Olomouc, Czech Republic; katerina.barton@upol.cz (K.B.T.); lukas.malina@upol.cz (L.M.)

4 Physics Department, University of Ioannina, 45110 Ioannina, Greece; bourlino@uoi.gr

* Correspondence: marketa.havrdova@upol.cz; Tel.: +420-585634384

\begin{abstract}
Fluorescent carbon dots (CDs) are potential tools for the labeling of cells with many advantages such as photostability, multicolor emission, small size, rapid uptake, biocompatibility, and easy preparation. Affinity towards organelles can be influenced by the surface properties of CDs which affect the interaction with the cell and cytoplasmic distribution. Organelle targeting by carbon dots is promising for anticancer treatment; thus, intracellular trafficking and cytotoxicity of cationic CDs was investigated. Based on our previous study, we used quaternized carbon dots (QCDs) for treatment and monitoring the behavior of two human cancer cell MCF-7 and HeLa lines. We found similarities between human cancer cells and mouse fibroblasts in the case of QCDs uptake. Time lapse microscopy of QCDs-labeled MCF-7 cells showed that cells are dying during the first two hours, faster at lower doses than at higher ones. QCDs at a concentration of $100 \mu \mathrm{g} / \mathrm{mL}$ entered into the nucleus before cellular death; however, at a dose of $200 \mu \mathrm{g} / \mathrm{mL}$, blebbing of the cellular membrane occurred, with a subsequent penetration of QCDs into the nuclear area. In the case of HeLa cells, the dose-depended effect did not happen; however, the labeled cells were also dying in mitosis and genotoxicity occurred nearly at all doses. Moreover, contrasted intracellular compartments, probably mitochondria, were obvious after $24 \mathrm{~h}$ incubation with $100 \mu \mathrm{g} / \mathrm{mL}$ of QCDs. The levels of reactive oxygen species (ROS) slightly increased after $24 \mathrm{~h}$, depending on the concentration, thus the genotoxicity was likely evoked by the nanomaterial. A decrease in viability did not reach IC 50 as the DNA damage was probably partly repaired in the prolonged G0/G1 phase of the cell cycle. Thus, the defects in the G2/M phase may have allowed a damaged cell to enter mitosis and undergo apoptosis. The anticancer effect in both cell lines was manifested mainly through genotoxicity.
\end{abstract}

Keywords: cationic carbon dots; fluorescence microspectroscopy; nucleus; cytotoxicity; genotoxicity; cancer cells; MCF-7; HeLa

\section{Introduction}

Over recent decades, the carbon dots (CDs) have been very popular as promising fluorescent probes due to their low photobleaching, lack of optical blinking, tunable photoluminescence, versatile surfaces, and excellent biocompatibility [1,2]. These excellent properties of CDs have made them prosperous in the applications of bioimaging, drug 
delivery, biochemical detection, and sensors [3-7]. Passivation of nanoparticles including $\mathrm{CDs}$ is a very commonly used procedure which equips the nanomaterials with different properties such as charge [8,9], fluorescence, surface specificity, and affinity to the cellular structures (cellular membrane, organelles, proteins, genes) [9] and influent cellular uptake [8,10], drug delivery [11-13], gene transfection efficacy [14-17], and general biological effects [18]. Synthesis of cationic carbon dots can be achieved by a facile ultrasonic method [19], green melting method [20], hydrothermal method [21,22], thermal oxidation [23-25]. Positively charged carbon dots are promising for in vitro applications (genetic engineering [26], biosensors [27], diagnosis [28], antibacterial agents [25]). They can show different behaviors in various cell lines, as we already studied with regard to healthy animal cell lines $[8,29,30]$. A variety of CDs have been applied for labeling different subcellular structures [31]; however, most CDs mainly accumulate in the cytoplasm, especially in endo/lysosomes, mitochondria, Golgi apparatus, and endoplasmic reticulum [32]. CDs have been studied also for nucleus labeling, photodynamic therapy, and optical monitoring of anticancer drugs [33-36]. DNA-damage can be caused by the small size of nanoparticles together with their surface charge and surface functional groups, which alters the interaction of CDs with cells [37]. Since many anticancer drugs are required to enter the cell nucleus where the drugs damage the genes to stop the proliferation of the cancer cell $[28,38,39]$, nucleus targeting, optical monitoring, genotoxic effect, inhibition of proliferation, and targeting of mitochondria are all regarded as crucial properties of nanomaterials for anticancer treatment. Thus, the present work is focused on QCDs trafficking and cytotoxic assays to obtain a comprehensive study for future anticancer drug delivery complexes.

\section{Results}

\subsection{Intracellular Observation of QCDs-Labeled MCF-7 Cells}

Cancer MCF-7 cell line was incubated with various doses of QCDs, i.e., 50, 100, 200, $400 \mu \mathrm{g} / \mathrm{mL}$ for $24 \mathrm{~h}$, and imaged (Figure 1). MCF-7 cells treated with $50 \mu \mathrm{g} / \mathrm{mL}$ of QCDs had full endo/lysosomes in perinuclear area (Figure 1a). Concentration of QCDs from $100 \mu \mathrm{g} / \mathrm{mL}$ changed the cellular morphology to the ring-shape (Figure 1b-d); thus, it was not possible to recognize whether the QCDs were present in the nucleus or not. For better information on interaction of cells with a nanomaterial, live monitoring was recorded immediately after addition of QCDs. It was obvious that QCDs enter into the nuclei after $45 \mathrm{~min}$ incubation with cells (see Figure 2) and after $24 \mathrm{~h}$, the cells revealed weak adherence and were dying, as in the case of L929 cells [29]. Weak adherence of labeled MCF-7 cells caused a decrease in a number of cells for imaging in higher doses. At a concentration of $200 \mu \mathrm{g} / \mathrm{mL}$, we observed that the penetration into the nuclei occurred surprisingly later (between 65-70 min, see Video S1) than at a concentration of $100 \mu \mathrm{g} / \mathrm{mL}$; however, the blebbing happened at the same time as the signal enriched the nuclei (Figure 3). Thus, according to microscopy evaluation, we know that the morphology of MCF-7 cells was significantly deformed at a dose of $100 \mu \mathrm{g} / \mathrm{mL}$ and that the presence of QCDs in the nuclei and nucleoli happened before cellular dying as blebbing of cellular membrane occurred after the QCDs contrasted the nuclear area of MCF-7 cells. Although, cells had weak adherence and viability was not reduced strongly, as witnessed from the cytotoxicity measurements (Figure 4a), we considered this dose as critical based on changes of morphology. The comet assay demonstrated a damage of DNA. A concentration of $50 \mu \mathrm{g} / \mathrm{mL}$ evoked a value of the tail less than $10 \%$ (please note: the "head" is intact DNA in the nucleus, the "tail" is damaged DNA migrated away from the nucleus; when the tail value is less than $10 \%$, the dose is non-genotoxic). At a concentration of $100 \mu \mathrm{g} / \mathrm{mL}$, the value of the tail was $14.11 \%$ (Figure $4 \mathrm{~b}$ ). Subsequently, genotoxicity was growing with the increasing concentration of QCDs and reached $50 \%$ at $400 \mu \mathrm{g} / \mathrm{mL}$ (see Figure $4 \mathrm{~b}$ ). In summary, very sensitive doses of QCDs for MCF-7 cells are 100 and $200 \mu \mathrm{g} / \mathrm{mL}$. However, the faster killing, monitored during the first two hours immediately after adding of the sample, occurred at a concentration of $100 \mu \mathrm{g} / \mathrm{mL}$. QCDs at higher concentrations covered the cells and 
restricted movement and proliferation. This is also viewed as a beneficial effect in antitumor treatment (Figure 5).

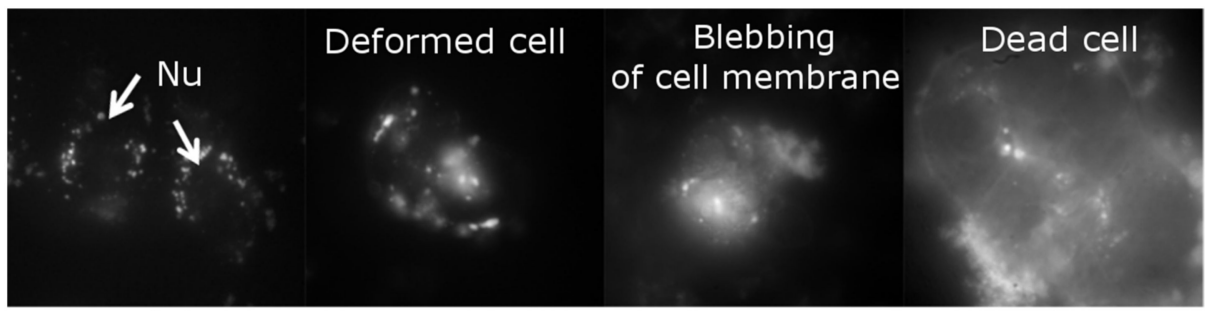

(a)

(b)

(c)

(d)

Figure 1. MCF-7 cells treated with concentrations of 50-400 $\mu \mathrm{g} / \mathrm{mL}$ of QCDs for $24 \mathrm{~h}:$ (a) $50 \mu \mathrm{g} / \mathrm{mL}$ : contrasted perinuclear area of two cells, "Nu" denotes nucleus area; (b) altered morphology of cell (ring-shape) caused by a concentration of $100 \mu \mathrm{g} / \mathrm{mL}$; (c) dying cell after incubation with $200 \mu \mathrm{g} / \mathrm{mL}-$ blebbing of cell membrane; (d) cluster of dead cells after exposure to $400 \mu \mathrm{g} / \mathrm{mL}$; FMS, the field of view was $91 \mu \mathrm{m}$ in images (a-c), and $55 \mu \mathrm{m}$ in image (d).
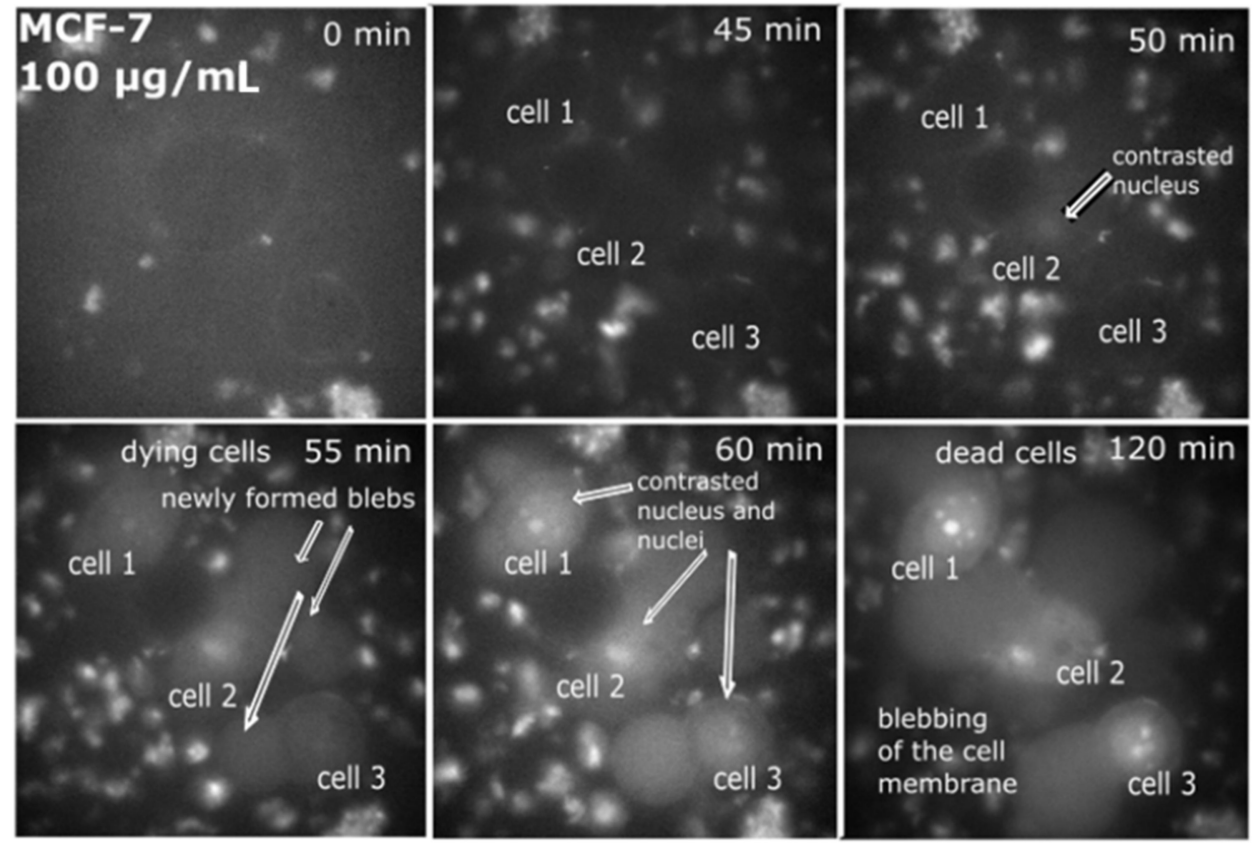

Figure 2. Live monitoring of MCF-7-labeled cells observed in growth medium; time 0 min = time immediately after addition of the solution with a concentration of $100 \mu \mathrm{g} / \mathrm{mL}$ of QCDs in the growth medium; at time $50 \mathrm{~min}$, it is obvious that the first nucleus was contrasted, after next $5 \mathrm{~min}$ (at time $55 \mathrm{~min}$ ), all the cells started blebbing, indicating the first sign of cellular death. FMS, total magnification 90, field of view $91 \mu \mathrm{m}$.

\subsection{Intracellular Observation of QCDs-Labeled HeLa Cells}

The same concentrations, conditions, and techniques were also used in the case of HeLa cells. At a concentration of $50 \mathrm{~g} / \mathrm{mL}$, QCDs were located in cytosol and around the nuclei in endo/lysosomes (Figure 6a); however, $100 \mu \mathrm{g} / \mathrm{mL}$ of QCDs filled the whole cytosol and probably interacted with mitochondria (see Figure 6b). Mitochondria in human cancer cells are closely related to cancer cell proliferation, invasion, metastasis, and drug-resistant mechanisms, making them promising target organelle for the anticancer treatment [40]. Carbon dots, from a concentration of $200 \mu \mathrm{g} / \mathrm{mL}$, entered into the nuclei (confirmed by live monitoring-QCDs entered in nucleus after $75 \mathrm{~min}$, see Video S2) and after $24 \mathrm{~h}$, they caused cellular death especially in mitotic cells (Figures 6c and 7). Those cells which survived the highest dose, i.e., $400 \mu \mathrm{g} / \mathrm{mL}$, of QCDs were massively deformed and detached, since after washing, the resulting number of cells was very low 
(Figure 6d). It seems that anticancer dose of QCDs for HeLa cells occurred at a concentration of $200 \mu \mathrm{g} / \mathrm{mL}$. Nevertheless, viability (Figure 8a) was gradually decreased at all the doses. To check the mechanisms behind different viability, and considering strong partitioning of QCDs into nucleus, we compared genotoxicity (Figure 8b).
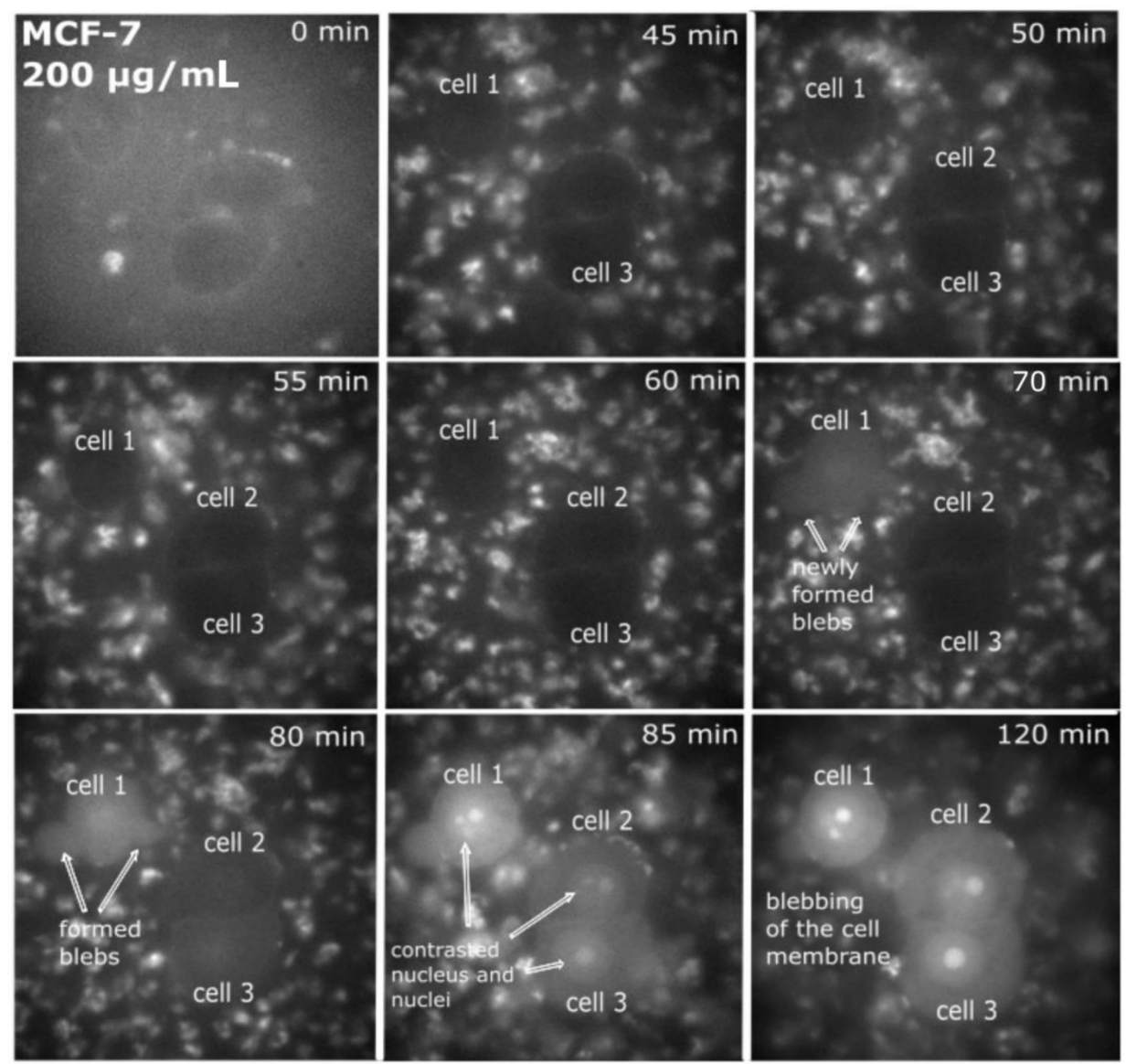

Figure 3. Live monitoring of MCF-7-labeled cells in growth medium; time $0 \mathrm{~min}=$ time immediately after addition of the solution with a concentration of $200 \mu \mathrm{g} / \mathrm{mL}$ of QCDs in the growth medium; first cell was contrasted at time $70 \mathrm{~min}$ and at this time, the first blebs also appeared; at $80 \mathrm{~min}$, contrasted nucleus was obvious and was enhanced with time and also other nuclei and nucleoli were tagged (see 85 and $120 \mathrm{~min}$ ). FMS, total magnification 90, field of view $91 \mu \mathrm{m}$.

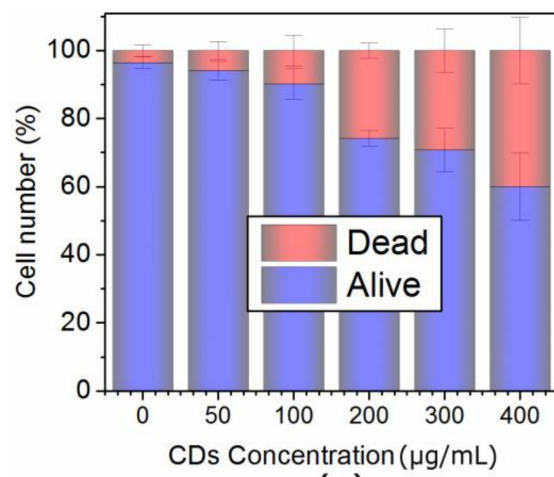

(a)

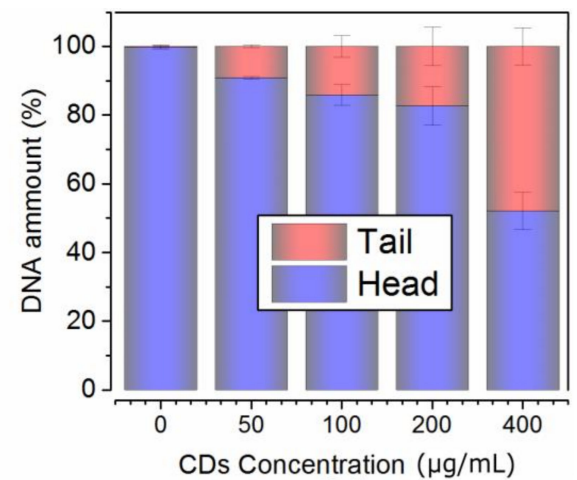

(b)

Figure 4. (a) Viability and (b) genotoxicity of MCF-7 cells exposed to the concentration line of QCDs after $24 \mathrm{~h}$ incubation. Please note genotoxicity terms: "head" is intact DNA in nucleus, "tail" is damaged DNA migrated away from the nucleus. When the tail value is more than $10 \%$, the dose is considered genotoxic [29]. 


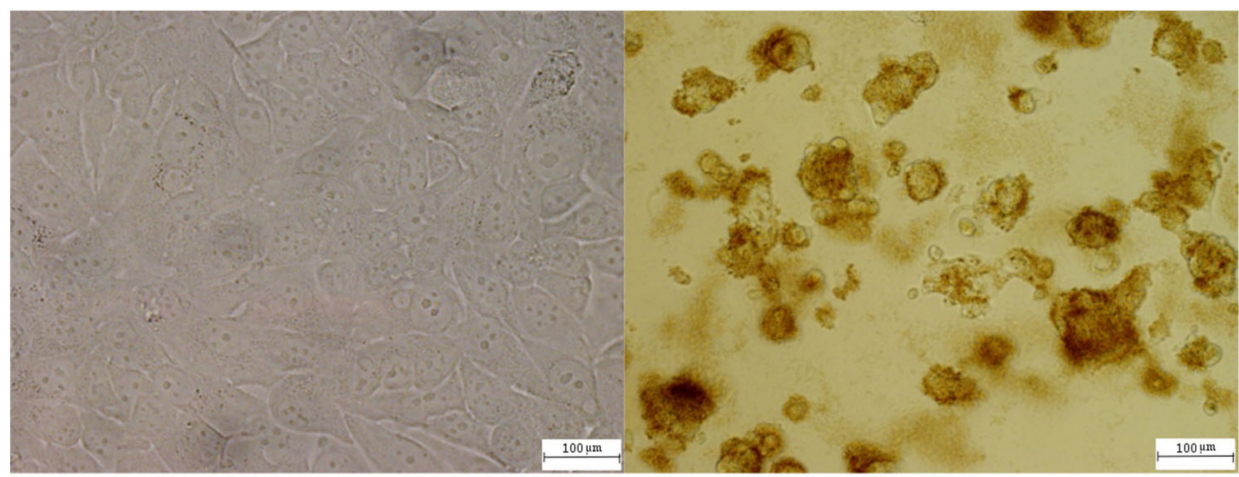

(a)

(b)

Figure 5. Light microscopy of MCF-7 cells: (a) non-labeled control cells, confluence $100 \%$; (b) the same number of cells labeled with $200 \mu \mathrm{g} / \mathrm{mL}$ of QCDs and their anticancer effect after $24 \mathrm{~h}$; scale bar $100 \mu \mathrm{m}$.

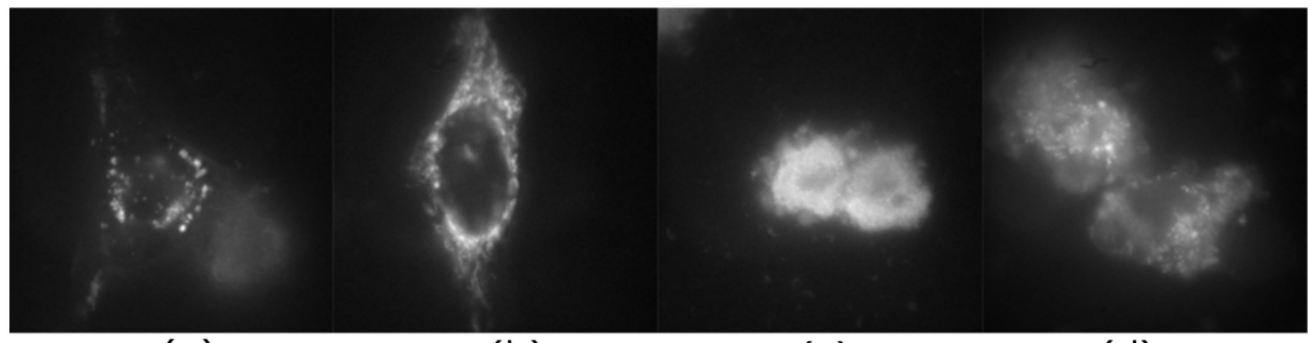

(a)

(b)

(c)

(d)

Figure 6. HeLa cells contrasted by $50-400 \mu \mathrm{g} / \mathrm{mL}$ of QCDs: (a) $50 \mu \mathrm{g} / \mathrm{mL}$ localization of endo/lysosomes filled by QCDs in perinuclear area; (b) QCD-contrasted mitochondria at a dose of $100 \mu \mathrm{g} / \mathrm{mL}$; (c) $200 \mu \mathrm{g} / \mathrm{mL}$ —critical dose for HeLa cells—death mainly of mitotic cells; (d) $400 \mu \mathrm{g} / \mathrm{mL}$-dead HeLa cells with blebs. FMS, total magnification 90, field of view $91 \mu \mathrm{m}$.

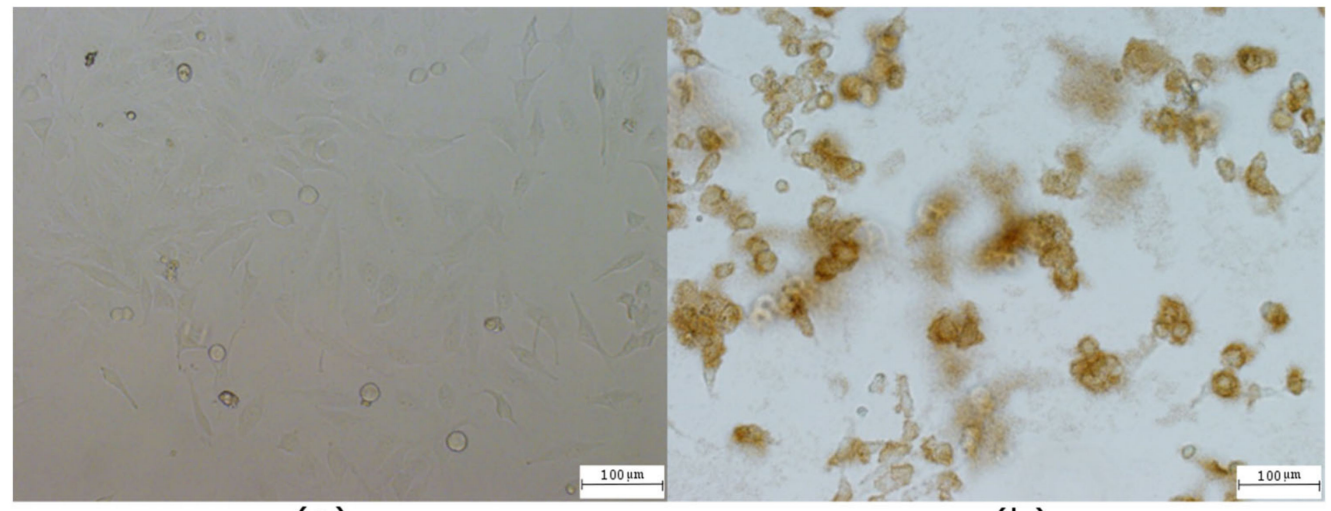

(a)

(b)

Figure 7. Light microscopy of HeLa cells: (a) non-labeled control cells, confluence $100 \%$, (b) the same number of cells labeled with $200 \mu \mathrm{g} / \mathrm{mL}$ of QCDs and their anticancer effect after $24 \mathrm{~h}$.

Genotoxicity in the HeLa cells occurred nearly at all the doses $(12.13 \%$ at $50 \mu \mathrm{g} / \mathrm{mL}$, $8.54 \%$ at $100 \mu \mathrm{g} / \mathrm{mL}, 13.42 \%$ at $200 \mu \mathrm{g} / \mathrm{mL}$, and $29.56 \%$ at $400 \mu \mathrm{g} / \mathrm{mL}$ )-Figure $8 \mathrm{~b}$. Despite the fact that QCDs enter into the nuclei and nucleoli, as also seen in our previously tested healthy cell lines NIH/3T3 and L929 [29], we can assume that they caused genotoxicity only in cancer MCF-7 and HeLa cells. Until now, only a few studies have focused on genotoxicity caused by carbon dots themselves [30,41]; CDs are usually examined as biosensors for DNA detection [42-45]. 


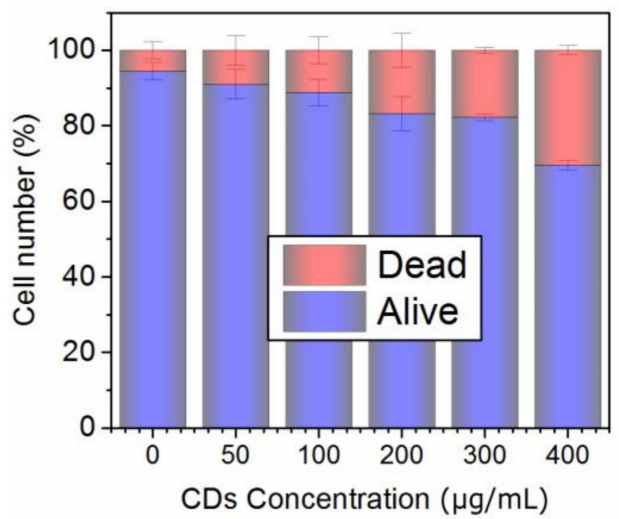

(a)

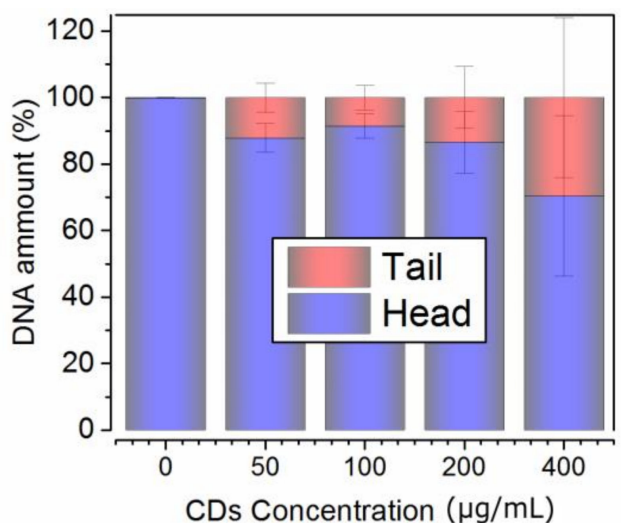

(b)

Figure 8. (a) Viability and (b) genotoxicity of HeLa cells exposed to the concentration line of QCDs after $24 \mathrm{~h}$ incubation. Please note genotoxicity terms: "head" is intact DNA in nucleus, "tail" is damaged DNA migrated away from the nucleus. When the tail value is more than $10 \%$, the dose is genotoxic [29].

\subsection{Concentration-Dependent Uptake and Oxidative Stress in Both Cell Lines}

Intracellular trafficking and cytotoxicity depend also on the surface properties of the sample and on the number of incorporated nanomaterials into the cells as it can disrupt cellular homeostasis [46]. From our microscopic results, especially on the MCF-7 cell line, it was obvious that the concentration of QCDs in the interval of $100-200 \mu \mathrm{g} / \mathrm{mL}$ evoked different contrasting and cellular death. Thus, we measured fluorescence intensity of QCDs in individual cells by flow cytometry and tried to reveal the cause of different cell sensitivity. Cells were incubated with QCDs at concentrations from 0 to $400 \mu \mathrm{g} / \mathrm{mL}$ for $24 \mathrm{~h}$ at $37^{\circ} \mathrm{C}$, then trypsinized and measured by flow cytometry (Figure 9). From the observed results, it is obvious that the uptake of both cell lines is similar at a concentration of $50 \mu \mathrm{g} / \mathrm{mL}$. At a dose of $100 \mu \mathrm{g} / \mathrm{mL}$, a high increase in the uptake of MCF-7 cells is observed in comparison to HeLa cells, for which the uptake occurs in a more gradual manner. This measurement confirmed the microscopic results because the highest uptake of MCF-7 cells is found between the concentrations of $100-200 \mu \mathrm{g} / \mathrm{mL}$, and the saturated concentration of QCDs is $200 \mu \mathrm{g} / \mathrm{mL}$ in the case of the HeLa cells.

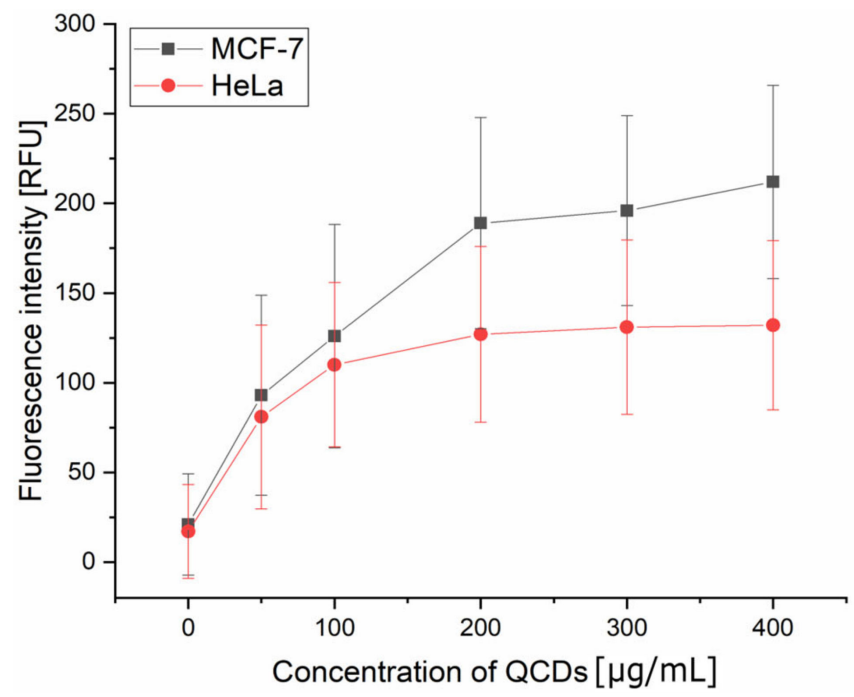

Figure 9. Concentration-dependent uptake of MCF-7 and HeLa cells, measured by flow cytometer. It needs to be mentioned that, for error bars in flow cytometry of concentration uptake measurement, values of coefficient of variations for events in each sample were used. 
This assay was measured in parallel with mouse NIH/3T3 and L929 fibroblasts and we found out interesting similarities between NIH/3T3 and HeLa cells vs. L929 and MCF-7 cells (see Figure S1). The main changes occurred at $100 \mu \mathrm{g} / \mathrm{mL}$, when similarity of uptake can be strongly visible in two groups (NIH/3T3 and HeLa cells vs. L929 and MCF-7 cells) and persisted up to the highest doses. These results showed that L929 and MCF-7 cells have a significantly stronger uptake than NIH/3T3 and HeLa cells. Quantitative determination of internalized CQDs in different cell lines was also described in the study [7] focused on the concentration-dependent photoluminescence of nitrogen-containing carbonaceous quantum dots (N-CQDs). Moreover, the authors in another study analyzed oxidative stress conditions by examining the cellular anti-oxidative capacity as a defensive response to the increasing concentration of N-CQDs [47].

Cellular uptake of the nanoparticles relates to the induction of intracellular reactive oxygen species (ROS) [48]. A low ROS level is generated by normal cell metabolism (physiological oxidative stress) whereas a high ROS production leads to oxidative damage of cells and death caused by excessive and toxic oxidative burden [49]. Thus, the oxidation stress of both cell lines was tested after $24 \mathrm{~h}$ incubation with QCDs (Figure 10). The ROS level was not significant up to $100 \mu \mathrm{g} / \mathrm{mL}$ and although subsequently ROS increased up to a concentration of $250 \mu \mathrm{g} / \mathrm{mL}$, the value of the ROS level was not high in comparison to other studies $[8,50]$. Therefore, the ROS production was not identified as the major mechanism of cell damage. The oxidative stress may also lead to the genomic instability [51], but according to these results, the genotoxicity was likely evoked by the nanomaterial.

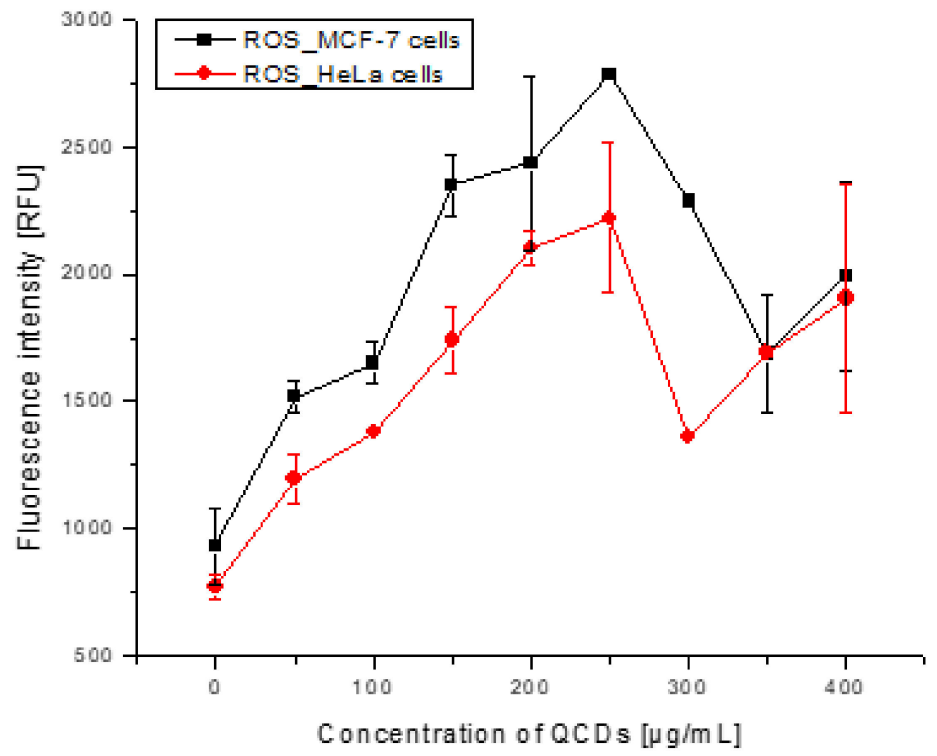

Figure 10. ROS level in MCF-7 and HeLa cells after $24 \mathrm{~h}$ incubation with different doses of QCDs.

Cellular damage depends on the repairing of DNA in the cell cycle, where only cells with intact DNA can continue to mitosis and cells with damaged DNA undergo cellular death [52]. Thus, the cell cycle profile was measured.

\subsection{Cell Cycle Analysis of MCF-7 and HeLa Cells}

The cell cycle profile was analyzed by the flow cytometer using the DNA kit (BD CycletestTM Plus DNA kit, East Rutherford, NJ, USA) as in our previous work [29]. The cell cycle of MCF-7 labeled by QCDs was found to show no significant changes at the concentrations of 50-300 $\mu \mathrm{g} / \mathrm{mL}$. Nevertheless, in comparison to the highest dose $(400 \mu \mathrm{g} / \mathrm{mL})$ with the control non-labeled cells, the G0/G1 phase was slightly prolonged and the G2/M phase shortened (Figure 11a). Defects in the G2/M phase may allow a damaged cell to enter mitosis and undergo apoptosis [53]. In the case of QCDs treated-HeLa cells, all doses affected the cell cycle profile because, with growing concentration of QCDs, the G0/G1 
phases were prolonged and G2/M phase shortened (Figure 11b). These changes can be a sign of low proliferation with increasing doses, of the entering of damaged cells in G0, and of the activation of apoptosis, or may be also a sign of the repairing of damaged DNA, which was confirmed in our genotoxicity measurement (Figure 8b).

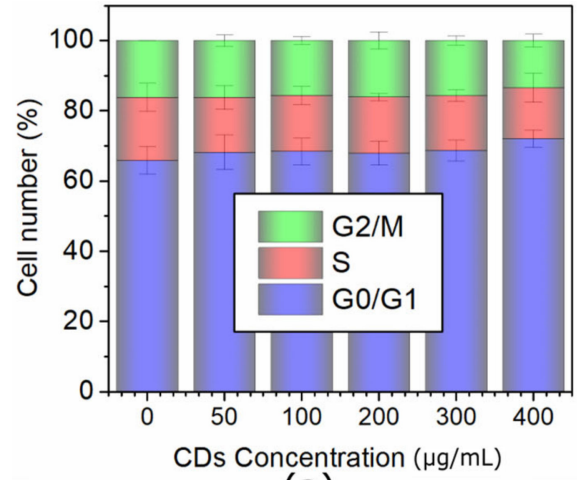

(a)

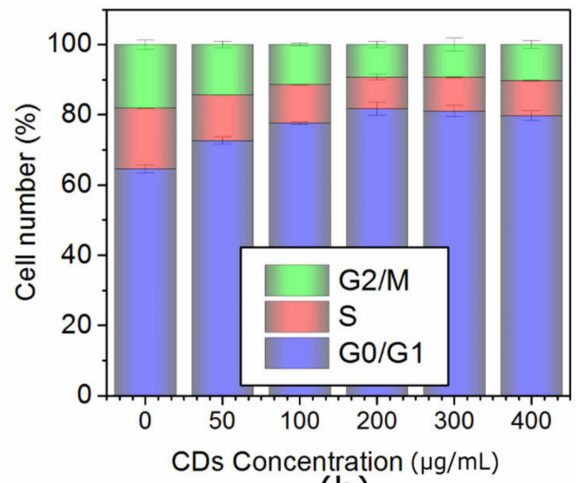

(b)

Figure 11. Cell cycle profile of cells labeled with QCDs: (a) human breast cancer MCF-7 cells, (b) human cervix cancer HeLa cells.

\section{Materials and Methods}

This work was performed in parallel with our previous study [29]; thus, the method is very similar or the same.

\subsection{Carbon Dots}

Quaternized carbon dots (QCDs) were prepared by thermal oxidation of a tris(hydroxy methyl)aminomethane (Tris) - betaine hydrochloride salt precursor, where Tris provides the carbon source and betaine the surface modifier [23]. The QCDs have sizes in the range 4-9 nm, quasi-spherical morphology (Figure 12), and display a positive zeta potential of $+43 \mathrm{mV}$ at neutral $\mathrm{pH}$ (e.g., the $\mathrm{pH}$ of the $\mathrm{QCDs}^{\prime}$ aqueous dispersion). The presence of $-\mathrm{N}\left(\mathrm{CH}_{3}\right)^{3+}$ groups in QCDs was evidenced by NMR spectroscopy, as well as, by the highly positive zeta potential at neutral $\mathrm{pH}$. Furthermore, based on elemental analysis and TGA, an anion-exchange capacity of $2.1 \mathrm{mmoL} \mathrm{g}^{-1}$ was estimated in the chloride form $\left(\mathrm{Cl}^{-}\right.$ions compensate the positively charged quaternary ammonium groups). Regarding the quantum yield of the dots $(4 \%)$, this was estimated for the blue part of the emission spectrum, where PL had the highest intensity. As we moved to greater wavelengths the emission, and hence the quantum yield of the dots, was significantly decreasing. High quantum yields are usually considered suspicious in terms of purity of the dots and origin of fluorescence [54]. In the present case, the value of $4 \%$ is typical of carbon dots void of any fluorescent impurities. In general, temperature synthesis below $200{ }^{\circ} \mathrm{C}$ favors the formation of molecular fluorophores that dramatically increase the quantum yield. However, removal of such impurities by extensive purification results in quantum yields of $1-3 \%$. On the other hand, temperature synthesis above $200{ }^{\circ} \mathrm{C}$ (as is true for our dots) results in higher degrees of carbonization and less fluorescent impurities formation with concurrent drop in quantum yield [55]. The purity of the dots used in this work was evidenced by capillary electrophoresis, where a narrow and single peak was noticed in the corresponding chromatograph. For more information on the material characterization, please see our previous studies [23,29].

\subsection{Cell Cultivation, Microscopy}

Both cell lines (MCF-7, HeLa) were purchased from American Type Culture Collection (ATCC, Manassas, VA, USA) and were cultivated in high glucose DMEM (Life Technologies, Carlsbad, CA, USA). Both media also contained 10\% fetal calf serum (FCS), 10,000 U/mL penicillin, and $10,000 \mu \mathrm{g} / \mathrm{mL}$ streptomycin. Cells were incubated at $37^{\circ} \mathrm{C}$ and under a 
$5 \% \mathrm{CO}_{2}$-enriched atmosphere. A light microscope Olympus IX 70 equipped with a phase contrast was used for control of cell confluence.

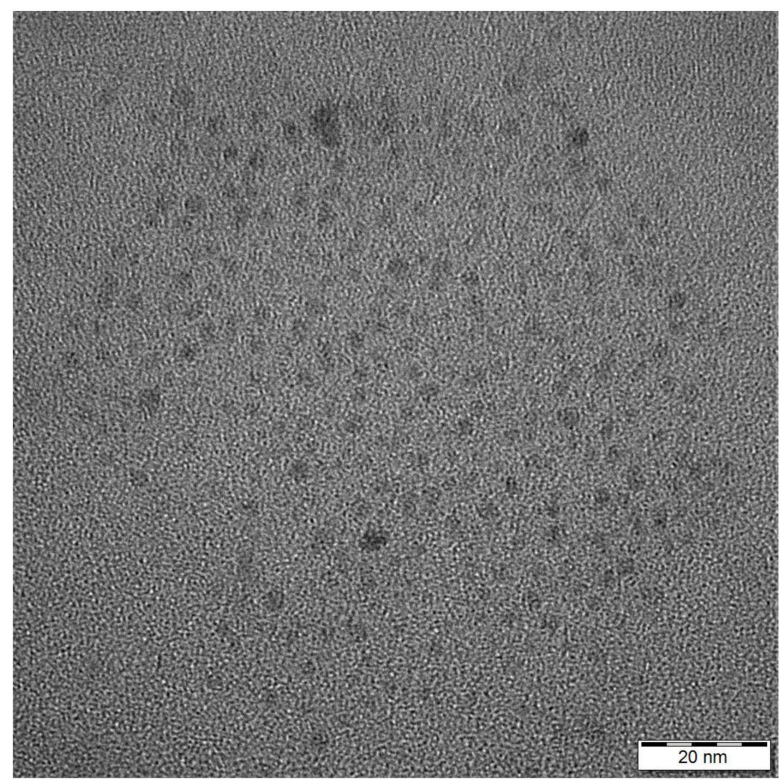

Figure 12. TEM image of QCDs, scale bare $20 \mathrm{~nm}$.

\subsection{Fluorescence Microspectroscopy}

MCF-7 or HeLa cells were seeded on glass-bottom cell culture dishes (NuncTM, ThermoFisher Scientific, Waltham, MA, USA) at a cell density of $7 \times 10^{3}$ and cultured for $24 \mathrm{~h}$ at $37{ }^{\circ} \mathrm{C}$ and $5 \% \mathrm{CO}_{2}$. The next day, QCDs were diluted in the cell medium and added to each culture dish to achieve the desired final concentration $(50,100,200$, or $400 \mu \mathrm{g} / \mathrm{mL}$ ), and left to incubate for $24 \mathrm{~h}$. Before imaging, the dishes were washed twice with PBS and filled with a solution of HEPES and PBS (1:9). For live monitoring of the uptake, images were taken for $2 \mathrm{~h}$ in 5-min intervals immediately after the addition of QCDs $(400 \mu \mathrm{g} / \mathrm{mL})$.

CDs were excited by widefield illumination with an $\mathrm{Hg}$ arc lamp (Sutter Lambda LS, Novato, CA, USA) through an excitation filter with the transmission window 430-490 nm, and emission was collected within 506-594 nm (all filters by Semrock, West Henrietta, NY, USA), using a $100 \times / 1.4$ oil immersion objective (Nikon, Tokyo, Japan). As reported previously [56], spectrally resolved images were acquired sequentially by scanning the transmission window of the liquid crystal tunable filter (Cri Varispec VIS-10-20, Cambridge Research \& Instrumentation, Inc., Hopkinton, MA, USA), placed in front of an EMCCD camera (Andor iXon3 897, Oxford Instruments, Oxfordshire, UK), at 5-nm steps. From each $3 \mathrm{D}$ dataset $(\mathrm{x}, \mathrm{y}, \lambda)$, spatially resolved emission spectra were extracted and analyzed using a custom spectral fitting software written in Wolfram Mathematica [57] to determine local intensities and spectral peak positions.

\subsection{Cell Cycle and Concentration-Dependent Uptake}

A BD FACSVerse flow cytometer (BD biosciences, East Rutherford, NJ, USA) was used for determination of cell cycle, concentration-dependent uptake, and endocytosis analysis. Cells were incubated $24 \mathrm{~h}$ with various concentration of QCDs and according to the BD protocol, DNA kit (BD CycletestTM Plus DNA kit, Becton Dickinson, East Rutherford, NJ, USA) was used. The fluorescent intensity of Propidium Iodide (PI) was measured using exc. $488 \mathrm{~nm} / \mathrm{em} .586 \mathrm{~nm}$ detector to define any changes in the phases of the cell cycle.

Concentration-dependent uptake was assessed based on the mean fluorescent intensity (MFI) of labeled cells. We used concentrations of 50, 100, 200, 300, and $400 \mu \mathrm{g} / \mathrm{mL}$ of QCDs and after $24 \mathrm{~h}$ incubation, the supernatant was removed, and cells gently washed with PBS solution ( $0.1 \mathrm{M}, \mathrm{pH} 7.4)$. Subsequently, cells were detached with trypsin $(0.25 \%$ in 
EDTA, Sigma-Aldrich, St. Louis, MO, USA), resuspended in $100 \mu \mathrm{L}$ of growth medium, and fluorescence intensity of labeled cells was measured with a flow cytometer.

\subsection{Viability}

Viability of cells treated with QCDs was investigated by a BD FACSVerse flow cytometer (BD Biosciences, East Rutherford, NJ, USA) using LIVE/DEAD®Viability/Cytotoxicity Kit (Thermofisher, Waltham, MA, USA). Both cell lines (MCF-7 and HeLa) were labeled with the concentration line of $0-400 \mu \mathrm{g} / \mathrm{mL}$ of QCDs and incubated $24 \mathrm{~h}$. Subsequently, cells were washed by PBS solution ( $0.1 \mathrm{M}, \mathrm{pH} 7.4)$, detached with trypsin $(0.25 \%$ in EDTA, Sigma-Aldrich, St. Louis, MO, USA), and resuspended in $300 \mu \mathrm{L}$ of growth medium. This LIVE/DEAD®Viability/Cytotoxicity Kit is the assay utilized to quantitate apoptotic cell death. Thus, cells were incubated with $2 \mu \mathrm{L}$ of ethidium bromide $(2 \mathrm{mM})$ a $2 \mu \mathrm{L}$ of calcein-AM $(50 \mu \mathrm{M})$, diluted in DMSO. The fluorescence signal was measured by flow cytometry (red-exc. 488/ em. 700, green-exc.488/em.527). Red signal of ethidium bromide marked dead cells because they lost membrane integrity. However, green cells had active intracellular esterases and catalyzed the non-fluorescent calcein-AM to highly fluorescent green calcein [29].

\subsection{Comet Assay}

Genotoxicity was studied by the comet assay which detects DNA damage. The principle of this method is based on single cell gel electrophoresis (SCGE), during which intact DNA stay in the nucleus (called "head") and damaged DNA migrate away from the nucleus (resemble "tail" of comet). Specific DNA fluorescent probe allows to compare fluorescent intensity of the nucleoid (head) and migrated DNA (tail) in the image analysis [58]. In our study, we followed the methods from the article [59]. Microscope slides were covered with $1 \%$ HMP agarose, thereafter, the cells were trypsinized, washed with DMEM with $10 \% \mathrm{FBS}$, and centrifuged ( $6 \mathrm{~min}, 1000 \mathrm{rpm})$. Agarose ( $85 \mu \mathrm{L}$ of $1 \% \mathrm{LMP}$ ) was added to the cell suspension and $85 \mu \mathrm{L}$ of this mixture was given to the microscope with agarose gel. The microscope slides were immersed in a lysis buffer for $1 \mathrm{~h}$, and then placed in an electrophoretic tank and dipped into a cool electrophoresis solution for $40 \mathrm{~min}$. Electrophoresis was run at $0.8 \mathrm{~V} / \mathrm{cm}$ and $380 \mathrm{~mA}$ for $20 \mathrm{~min}$. Finally, slides were neutralized in buffer $(0.4 \mathrm{M}$ Tris, $\mathrm{pH}=7.5)$ and the samples were stained with $S Y B R \circledast G$ reen and immediately scored using SW Comet Score [29].

\subsection{Reactive Oxygen Species}

Intracellular oxidative stress caused by QCDs was investigated by ROS analysis. At first, MCF-7 and HeLa cells were treated with 50-400 $\mu \mathrm{g} / \mathrm{mL}$ of QCDs and incubated for $24 \mathrm{~h}$. After incubation, the growth medium containing QCDs was removed and replaced by PBS solution ( $20 \mu \mathrm{L}$ per well) containing fluorescence ROS probe (pre-dissolved in DMSO, $500 \mathrm{mmoL} \times \mathrm{L}^{-1}$, General Oxidative Stress Indicator CM-H2DCFDA, Life Technologies) $[8,60]$. The fluorescence signal was measured by a microplate reader PRO M200 (Tecan, Austria) with excitation/emission wavelength of 505/529 nm [8].

\section{Conclusions}

In this work, we observed different sensitivity of two cancer cell lines to cationic carbon dots with an average size of $7 \mathrm{~nm}$, and similarity between human cancer cells and mouse fibroblasts in the uptake of QCDs. Time lapse microscopy of QCDs-labeled MCF-7 cells showed that morphology changes and targeting of the nuclei occurred faster at a lower dose than at a higher one but just in case of the $2 \mathrm{~h}$ measurement, which was performed immediately after the addition of QCDs into the growth medium. Viability after $24 \mathrm{~h}$ did not change significantly at a concentration of $100 \mu \mathrm{g} / \mathrm{mL}$, but the morphology of MCF-7 was still deformed. From the same concentration, genotoxicity was pronounced. In the case of HeLa cells, the dose-depended effect during the first $2 \mathrm{~h}$ did not happen; however, cells incubated with $200 \mu \mathrm{g} / \mathrm{mL}$ for $24 \mathrm{~h}$ were dying mainly in mitosis, probably because 
of weaker adherence. Genotoxicity occurred nearly at all the doses; moreover, contrasted subcellular compartments (probably mitochondria) were obvious after $24 \mathrm{~h}$ incubation with $100 \mu \mathrm{g} / \mathrm{mL}$ of QCDs. Knowledge of the intracellular fate of carbon dots is useful in a wide range of biological and biomedical applications. This sample deformed cellular shape, entering into the nucleus, causing mitotic catastrophe, and restricting movement and proliferation, which can all be viewed as beneficial effects in antitumor treatment.

Supplementary Materials: The following supporting information can be downloaded at: https:/ / www.mdpi.com/article/10.3390/ijms23031077/s1.

Author Contributions: M.H.: conceptualization, investigation on cell lines, methodology, writingoriginal draft, drawing of the illustrations, editing; I.U.: writing-review, data evaluation from FMS and consultation, methodology; K.B.T.: consultation of the results of the comet assay, methodology; L.M.: measurement of comet assay; K.P.: cytotoxic measurement; consultation; J.Š.: conceptualization, consultation of the results from FMS; A.B.B.: synthesis of the QCDs. All authors have read and agreed to the published version of the manuscript.

Funding: The work was supported by the ERDF project for the development of pre-applied research in nanotechnology and biotechnology (No. CZ.02.1.01/0.0/0.0/17_048/0007323). The authors gratefully acknowledge support from the project Nano4Future: No. CZ.02.1.01/0.0/0.0/16_019/0000754 and The Ministry of Health of the Czech Republic-MZČR-NU21-09-00357. All rights reserved. The work was supported also by the European Regional Development Fund-Project ENOCH (No. CZ. 02.1.01/0.0/0.0/16_019/0000868) and I.U. and J.Š. thank the Slovenian Research Agency for funding (research program P1-0060).

Institutional Review Board Statement: Not applicable.

Data Availability Statement: Not applicable.

Acknowledgments: Markéta Havrdová would like to thank all coauthors for their cooperation, Klara Čépe for the TEM image of QCDs and Tomas Malina for cytotoxic measurement.

Conflicts of Interest: The funders had no role in the design of the study; in the collection, analyses, or interpretation of data; in the writing of the manuscript, or in the decision to publish the results.

\section{References}

1. Baker, S.N.; Baker, G.A. Luminescent carbon nanodots: Emergent Nanolights. Angew. Chem. Int. Ed. 2010, 49, 6726-6744. [CrossRef]

2. Li, H.; Kang, Z.; Liu, Y.; Lee, S.-T. Carbon nanodots: Synthesis, properties and applications. J. Mater. Chem. 2012, 22, 24230-24253. [CrossRef]

3. Song, Y.; Shi, W.; Chen, W.; Li, X.; Ma, H. Fluorescent carbon nanodots conjugated with folic acid for distinguishing folatereceptor-positive cancer cells from normal cells. J. Mater. Chem. 2012, 22, 12568-12573. [CrossRef]

4. Ruan, S.; Qian, J.; Shen, S.; Zhu, J.; Jiang, X.; He, Q.; Gao, H. A simple one-step method to prepare fluorescent carbon dots and their potential application in non-invasive glioma imaging. Nanoscale 2014, 6, 10040-10047. [CrossRef] [PubMed]

5. Liu, J.-M.; Lin, L.-P.; Wang, X.-X.; Lin, S.-Q.; Cai, W.-L.; Zhang, L.-H.; Zheng, Z.-Y. Highly selective and sensitive detection of Cu ${ }^{2+}$ with lysine enhancing bovine serum albumin modified-carbon dots fluorescent probe. Analyst 2012, 137, 2637-2642. [CrossRef]

6. Kuo, T.R.; Sung, S.Y.; Hsu, C.W.; Chang, C.J.; Chiu, T.C.; Hu, C.C. One-pot green hydrothermal synthesis of fluorescent nitrogen-doped carbon nanodots for in vivo bioimaging. Anal. Bioanal. Chem. 2016, 408, 77-82. [CrossRef] [PubMed]

7. Wisniewski, M.; Czarnecka, J.; Bolibok, P.; Swidzinski, M.; Roszek, K. New insight into the fluorescence quenching of nitrogencontaining carbonaceous quantum dots-From surface chemistry to biomedical applications. Materials 2021, 14, 2454. [CrossRef]

8. Havrdova, M.; Hola, K.; Skopalik, J.; Tomankova, K.; Petr, M.; Cepe, K.; Polakova, K.; Tucek, J.; Bourlinos, A.B.; Zboril, R. Toxicity of carbon dots-Effect of surface functionalization on the cell viability, reactive oxygen species generation and cell cycle. Carbon. 2016, 99, 238-248. [CrossRef]

9. Zhu, Z.; Li, Q.; Li, P.; Xun, X.; Zheng, L.; Ning, D.; Su, M. Surface charge controlled nucleoli selective staining with nanoscale carbon dots. PLoS ONE 2019, 14, e0216230. [CrossRef] [PubMed]

10. Fröhlich, E. The role of surface charge in cellular uptake and cytotoxicity of medical nanoparticles. Int. J. Nanomed. 2012, 7, 5577-5591. [CrossRef] [PubMed]

11. Zhou, L.; Li, Z.; Liu, Z.; Ren, J.; Qu, X. Luminescent carbon dot-gated nanovehicles for pH-triggered intracellular controlled release and imaging. Langmuir 2013, 29, 6396-6403. [CrossRef]

12. Patra, S.; Roy, E.; Madhuri, R.; Sharma, P.K. The next generation cell-penetrating peptide and carbon dot conjugated nano-liposome for transdermal delivery of curcumin. Biomater. Sci. 2016, 4, 418-429. [CrossRef] [PubMed] 
13. Fahmi, M.Z.; Chen, J.K.; Huang, C.C.; Ling, Y.C.; Chang, J.Y. Phenylboronic acid-modified magnetic nanoparticles as a platform for carbon dot conjugation and doxorubicin delivery. J. Mater. Chem. B 2015, 3, 5532-5543. [CrossRef]

14. Misra, S.K.; Ohoka, A.; Kolmodin, N.J.; Pan, D. Next generation carbon nanoparticles for efficient gene therapy. Mol. Pharm. 2015, 12, 375-385. [CrossRef] [PubMed]

15. Pierrat, P.; Wang, R.; Kereselidze, D.; Lux, M.; Didier, P.; Kichler, A.; Pons, F.; Lebeau, L. Efficient in vitro and in vivo pulmonary delivery of nucleic acid by carbon dot-based nanocarriers. Biomaterials 2015, 51, 290-302. [CrossRef] [PubMed]

16. Wang, L.; Wang, X.; Bhirde, A.; Cao, J.; Zeng, Y.; Huang, X.; Sun, Y.; Liu, G.; Chen, X. Carbon-dot-based two-photon visible nanocarriers for safe and highly efficient delivery of siRNA and DNA. Adv. Healthc. Mater. 2014, 3, 1203-1209. [CrossRef]

17. Das, S.; Debnath, N.; Cui, Y.; Unrine, J.; Palli, S.R. Chitosan, Carbon Quantum Dot, and Silica Nanoparticle Mediated dsRNA Delivery for Gene Silencing in Aedes aegypti: A Comparative Analysis. ACS Appl. Mater. Interfaces 2015, 7, 19530-19535. [CrossRef]

18. Shi, H.; Wei, J.; Qiang, L.; Chen, X.; Meng, X. Fluorescent carbon dots for bioimaging and biosensing applications. J. Biomed. Nanotech. 2014, 10, 2677-2699. [CrossRef]

19. Yang, W.; Ni, J. Cationic carbon dots for modification-free detection of hyaluronidase. Anal. Chem. 2017, 89, 8384-8390. [CrossRef]

20. Feng, F.; Miao, C. Positively charged and $\mathrm{pH} /$ sensitive carbon dots for fluorescence detection of copper ion. Bull. Korean Chem. Soc. 2020, 42, 227-234. [CrossRef]

21. Fang, H.Y.; Huang, W.M.; Chen, D.H. One step synthesis of positively charged bifunctional carbon dot/silver composite. Nanotechnology 2019, 30, 365603. [CrossRef]

22. Wang, H.; Lu, F.; Ma, C.; Ma, Y.; Zhang, M.; Wang, B.; Zhang, Y.; Liu, Y.; Huang, H.; Kang, Z. Carbon dots with positive surface charge from teraric acid and m-aminophenol for selective killing of Gram-positive bacteria. J. Mater. Chem. B 2021, 9, 125-130. [CrossRef] [PubMed]

23. Bourlinos, A.B.; Zboril, R.; Petr, J.; Bakandritsos, A.; Krysmann, M.; Giannelis, E.P. Luminescent surface quaternized carbon dots. Chem. Mater. 2012, 24, 6-8. [CrossRef]

24. Song, Y.; Wang, Y.; Zhang, N.; Li, X.; Bai, X.; Li, T. Quaternized carbon-based nanoparticles embedded positively charged composite membranes towards efficient removal of cationic small-sized contaminants. J. Membr. Sci. 2021, 630, 119332. [CrossRef]

25. Hao, X.; Huang, L.; Zhao, C.; Chen, S.; Lin, W.; Lin, Y.; Zhang, L.; Sun, A.; Miao, C.; Lin, X.; et al. Antibacterial activity of positively charged carbon quantum dots without detectable resistance for wound healing with mixed bacteria infection. Mater. Sci. Eng. C 2021, 123, 111971. [CrossRef]

26. Zuo, G.; Xie, A.; Pan, X.; Su, T.; Li, J.; Dong, W. Fluorine-Doped Cationic Carbon Dots for Efficient Gene Delivery. ACS Appl. Nano Mater. 2018, 1, 2376-2385. [CrossRef]

27. Guo, R.B.; Chen, B.; Li, F.L.; Weng, S.H.; Zheng, Z.F.; Chen, M.; Wu, W.; Lin, X.H.; Yang, C.Y. Positive carbon dots with dual roles of nanoquencher and reference signal for the ratiometric fluorescence sensing of DNA. Sens. Actuators B Chem. 2018, 264, 193-201. [CrossRef]

28. Yue, L.J.; Wei, Y.Y.; Fan, J.B.; Chen, L.; Li, Q.; Du, J.L.; Yu, S.P.; Yang, Y.Z. Research progress in the use of cationic carbon dots for the integration of cancer diagnosis with gene treatment. New Carbon Mater. 2021, 36, 373-389. [CrossRef]

29. Havrdova, M.; Urbancic, I.; Barton Tomankova, K.; Malina, L.; Strancar, J.; Bourlinos, A.B. Self-targeting of carbon dots into the cell nucleus: Diverse mechanisms of toxicity in NIH/3T3 and L929 cells. Int. J. Mol. Sci. 2021, 22, 5608. [CrossRef]

30. Malina, T.; Polakova, K.; Skopalik, J.; Milotova, V.; Hola, K.; Havrdova, M.; Tomankova, K.B.; Cmiel, V.; Sefc, L.; Zboril, R. Carbon dots for in vivo fluorescence imaging of adipose tissue-derived mesenchymal stromal cells. Carbon 2019, 152, 434-443. [CrossRef]

31. Unnikrishnan, B.; Wu, R.S.; Wei, S.C.; Huang, C.C.; Chang, H.; Chang, H.T. Fluorescent carbon dots for selective labeling of subcellular organelles. ACS Omega 2020, 5, 11248-11261. [CrossRef]

32. Jung, Y.K.; Shin, E.; Kim, B.-S. Cell nucleus-targeting zwitterionic carbon dots. Sci. Rep. 2015, 5, 18807. [CrossRef] [PubMed]

33. Hill, S.A.; Sheikh, S.; Zhang, Q.; Sueiro Ballesteros, L.; Herman, A.; Davis, S.A.; Morgan, D.J.; Berry, M.; Benito-Alifonso, D.; Galan, M.C. Selective photothermal killing of cancer cells using LED-activated nucleus targeting fluorescent carbon dots. Nanoscale Adv. 2019, 1, 2840-2846. [CrossRef]

34. Yang, L.; Jiang, W.; Qiu, L.; Jiang, X.; Zuo, D.; Wang, D.; Yang, L. One pot synthesis of highly luminescent polyethylene glycol anchored carbon dots functionalized with a nuclear localization signal peptide for cell nucleus imaging. Nanoscale 2015, 7, 6104-6113. [CrossRef]

35. Ci, J.; Tian, Y.; Kuga, S.; Niu, Z.; Wu, M.; Huang, Y. One-pot green synthesis of nitrogen-doped carbon quantum dots for cell nucleus labeling and copper(II) detection. Chem.-Asian J. 2017, 12, 2916-2921. [CrossRef] [PubMed]

36. Yuan, Y.; Guo, B.; Hao, L.; Liu, N.; Lin, Y.; Guo, W.; Li, X.; Gu, B. Doxorubicin-loaded environmentally friendly carbon dots as a novel drug delivery system for nucleus targeted cancer therapy. Colloids Surf. B 2017, 159, 349-359. [CrossRef] [PubMed]

37. Şimşek, S.; Şüküroğlu, A.A.; Yetkin, D.; Özbek, B.; Battal, D.; Genç, R. DNA-damage and cell cycle arrest initiated anti-cancer potency of super tiny carbon dots on MCF7 cell line. Sci Rep. 2020, 10, 13880. [CrossRef]

38. Zhang, J.; Zhao, X.; Xian, M.; Dong, C.; Shuang, S. Folic acid-conjugated green luminescent carbon dots as a nanoprobe for identifying folate receptor-positive cancer cells. Talanta 2018, 183, 39-47. [CrossRef]

39. Wang, J.; Liu, S.; Chang, Y.; Fang, L.; Han, K.; Li, M. High efficient delivery of siRNA into tumor cells by positively charged carbon dots. J. Macromol. Sci. A 2018, 55, 770-774. [CrossRef] 
40. Abe, J.; Yamada, Y.; Harashima, H. Validation of a Strategy for Cancer Therapy: Delivering Aminoglycoside Drugs to Mitochondria in HeLa Cells. J. Pharm. Sci. 2016, 105, 734-740. [CrossRef]

41. Sima, M.; Vrbova, K.; Zavodna, T.; Honkova, K.; Chvojkova, I.; Ambroz, A.; Klema, J.; Rossnerova, A.; Polakova, K.; Malina, T.; et al The Differential Effect of Carbon Dots on Gene Expression and DNA Methylation of Human Embryonic Lung Fibroblasts as a Function of Surface Charge and Dose. Int. J. Mol. Sci. 2020, 21, 4763. [CrossRef]

42. Singh, S.; Singh, M.K.; Das, P. Biosensing of solitary and clustered abasic site DNA damage lesions with copper nanoclusters and carbon dots. Sens. Actuators B Chem. 2018, 255, 763-774. [CrossRef]

43. Wang, Y.; Wang, S.; Ge, S.; Wang, S.; Yan, M.; Zang, D.; Yu, J. Facile and sensitive paper-based chemiluminescence DNA biosensor using carbon dots dotted nanoporous gold signal amplification label. Anal. Methods 2013, 5, 1328-1336. [CrossRef]

44. Huang, Q.T.; Lin, X.F.; Zhu, J.J.; Tong, Q.X. Pd-Au@carbon dots nanocomposite: Facile synthesis and application as an ultrasensitive electrochemical biosensor for determination of colitoxin DNA in human serum. Biosens. Bioelectron. 2017, 94, 507-512. [CrossRef] [PubMed]

45. Kudr, J.; Richtera, L.; Xhaxhiu, K.; Hynek, D.; Heger, Z.; Zitka, O.; Adam, V. Carbon dots based FRET for the detection of DNA damage. Biosens. Bioelectron. 2017, 92, 133-139. [CrossRef] [PubMed]

46. Zhang, L.W.; Monteiro-Riviere, N.A. Mechanisms of Quantum Dot Nanoparticle Cellular Uptake. Toxicol. Sci. 2009, 110, 138-155 [CrossRef] [PubMed]

47. Czarnecka, J.; Kwiatkowski, M.; Wisniewski, M.; Roszek, K. Protein corona hinders N-CQDs oxidative potential and favors their application as nanobiocatalytic system. Int. J. Mol. Sci. 2021, 22, 8136. [CrossRef] [PubMed]

48. Sies, H.; Berndt, C.; Jones, D.J. Oxidative Stress. Annu. Rev. Biochem. 2017, 86, 715-748. [CrossRef]

49. Zhou, Y.; Sun, H.; Wang, F.; Ren, J.; Qu, X. How functional groups influence the ROS generation and cytotoxicity of graphene quantum dots. Chem. Commun. 2017, 53, 10588-10591. [CrossRef] [PubMed]

50. Tomankova, K.; Horakova, J.; Harvanova, M.; Malina, L.; Soukupova, J.; Hradilova, S.; Kejlova, K.; Malohlava, J.; Licman, L.; Dvorakova, M.; et al. Cytotoxicity, cell uptake and microscopic analysis of titanium dioxide and silver nanoparticles in vitro. Food Chem. Toxicol. 2015, 82, 106-115. [CrossRef]

51. Periasamy, V.S.; Athinarayanan, J.; Alfawaz, M.A.; Alshatwi, A.A. Carbon nanoparticle induced cytotoxicity in human mesenchymal stem cells through upregulation of TNF3, NFKBIA and BCL2L1 genes. Chemosphere 2016, 144, 275-284. [CrossRef] [PubMed]

52. Foster, I. Cancer: A cell cycle defect. Radiography 2008, 14, 144-149. [CrossRef]

53. DiPaola, R.S. To arrest or not to G2-M cell-cycle arrest. Clin. Cancer Res. 2002, 8, 3512-3519.

54. Essner, J.B.; Kist, J.A.; Polo-Parada, L.; Baker, G.A. Artifacts and errors associated with the ubiquitous presence of fluorescent impurities in carbon nanodots. Chem. Mater. 2018, 30, 1878-1887. [CrossRef]

55. Krysmann, M.J.; Kelarakis, A.; Dallas, P.; Giannelis, E.P. Formation mechanism of carbogenic nanoparticles with dual photoluminescence emission. J. Am. Chem. Soc. 2012, 134, 747-750. [CrossRef] [PubMed]

56. Arsov, Z.; Urbančič, I.; Garvas, M.; Biglino, D.; Ljubetič, A.; Koklič, T.; Štrancar, J. Fluorescence microspectroscopy as a tool to study mechanism of nanoparticles delivery into living cancer cells. Biomed. Opt. Express 2011, 2, 2083-2095. [CrossRef] [PubMed]

57. Urbančič, I.; Arsov, Z.; Ljubetič, A.; Biglino, D.; Štrancar, J. Bleaching-corrected fluorescence microspectroscopy with nanometer peak position resolution. Opt. Express 2013, 21, 25291-25306. [CrossRef]

58. Collins, A.R. The comet assay for DNA damage and repair: Principles, applications, and limitations. Mol. Biotechnol. 2004, 26, 249-261. [CrossRef]

59. Tomankova, K.; Kejlova, K.; Binder, S.; Daskova, A.; Zapletalova, J.; Bendova, H.; Kolarova, H.; Jirova, D. In vitro cytotoxicity and phototoxicity study of cosmetics colorants. Toxicol Vitr. 2011, 25, 1242-1250. [CrossRef]

60. Tomankova, K.; Kolarova, H.; Bajgar, R.; Jirova, D.; Kejlova, K.; Mosinger, J. Study of the photodyamic effect on the A549 cell line by atomic force microscopy and the influence of greeen tea extract on the production of reactive oxygen species. Ann. N. Y. Acad. Sci. 2009, 1171, 549-558. [CrossRef] 